\title{
PENERAPAN PRINSIP-PRINSIP GOOD GOVERNANCE OLEH EKSKLUSIFITAS AKTOR DI MAKASSAR
}

\author{
Ummu Habibah Gaffar \\ FISIP, Universitas Palangka Raya \\ Email: ummuhabibahgaffar@fisip.upt.ac.id
}

\begin{abstract}
This research will further explore the practice of Good Financial Goverance (GFD), with a case study of the partnership process that occurred between the Makassar City Government and PT GMTD in financial management for local government equity participation. This study will focus on actor relationships that occur between actors involved in partnerships as a recipe offered by Good Financial Governance. The research objective was to see the exclusivity of actors in good financial governance. This study used a qualitative method with the research location in Makassar, South Sulawesi, Indonesia.
\end{abstract}

Keyword : Exclusivity of Actor, Good Governance, Capital Governance

\section{PENDAHULUAN}

Selama ini perdebatan tentang good governance di Indonesia sangat terbatas. Perdebatan yang ada hanya berlangsung pada demensi proses atau jika tidak pada dimensi implementasi (Riyadi, Santoso and Alim :2018, Ukhriyawati, Ratnawati and Siyadi :2017, Kittie Uda, Schouten \& Hein : 2018). Fokus utama lebih banyak diarahkan untuk menjawab pertanyaan tentang bagaimana seharusnya pemerintahan yang baik, dan disaat yang sama belum banyak studi yang menyentuh dimensi aktor, dengan studi yang diarahkan untuk menjawab pertanyaan kepada siapa pemerintahan yang baik harus mengelola sistem pemerintahaan yang baik dan bagaimana membangun hubungan kemitraan yang baik dengan aktor lain pada good governance.

Tidak heran jika selama ini kehadiran good governance membuat perhatian para sarjana hanya terbagi menjadi dua kubu yang saling bertentangan gagasan. Satu kubu menaruh sikap optimis melihat praktek good governance yang berlangsung di Indonesia (Fernandes and Raffles :2017, Pal and Zaki :2016). Bagi kubu ini, good governance telah membuka ruang pasrtisipasi dan meningkatkan kerjasama pada masyarakat. Keterlibatan masyarakat pada arena pengambilan kebijakan menjadi satu terobosan baru, yang menurutnya satu kemajuan dalam sistem pemerintahan di Indonesia. Gagasan ini diperkuat dengan menunjukan bukti pada beberapa

11 | Ummu Habibah Gaffar | Eksklusifitas..... kasus seperti keterlibatan masyarakat dalam mencegah kebakaran hutan di Indonesia, serta munculnya komunitas-komunitas yang basisnya dari masyarakat sebagai wujud dari partisipasi.

Sementara pada kubu yang lain cenderung pesimis dengan kehadiran konsep good governance. Sikap pesimis dengan mempersoalkan good governance yang kehadirannya bergandengan dengan desentralisasi dibanyak sektor, termasuk desentralisasi fiskal. Para sarjana di kubu ini beranggapan jika good governance tidak berkontribusi banyak untuk sistem pemerintahan yang lebih baik, malah menuduh jika good governance selama ini telah mengikis ruang demokratisasi, mengabaikan keberadaan politik elit lokal dan bentuk partisipasi masyarakat (Hein: 2017, Voorst: 2015, Pierskalla and Aundrey: 2015). Gagasan ini dihadirkan setelah mengamati praktik good governance yang berlangsung di skala lokal di berbagai daerah di Indonesia. Kematangan berdemokrasi yang tidak diperkuat dengan pelembagaan ruang partisipasi serta saluran politik pada masyarakat lokal menjadi penyebab utama degradasi demokratisasi di tingkat lokal. Sehingga, ketika good governance yang salah satunya menghendaki keterlibatan civil society untuk mengambil peran cenderung tersisih oleh akusisi para aktor governance yang lain. 
Selain itu, para pengkritik juga melihat sisi lain yang dianggap masih terdapat kelemahan pada good governace adalah selama ini sudut pandang yang dibangun lebih kepada menyoroti proses akutabilitas dan partisipasi (Fossati: 2017, Husen dkk: 2017, Fernandes and Raffles :2017, Pal and Zaki :2016). Gagasan ini sepenuhnya mempersoalkan mekanisme pertanggung jawaban pada good governance. Kubu ini melihat, efek yang ditimbulkan dengan adanya good governance adalah ruang publik yang sebelumnya sangat ekslusif menjadi semakin terbuka. Masyarakat bisa mengakses setiap informasi layanan yang akan dan sementara dilakukan oleh pemerintah, termasuk untuk anggaran, masyarakat punya ruang untuk ikut terlibat mengawasi proses penganggaran mulai dari perencanaan hingg pada pelaporan. Namun, pada prakteknya, ketika proses pertanggung jawaban masyarakat mulai terpinggirkan dari proses yang sejak awal sangat terbuka. Tidak heran jika tuduhan sebagai syarat mendapatkan "legalitas formil" dari masyarakat sebagai bentuk protes terhadap pertanggung jawaban yang cenderung tertutup. Merangkul di awal, kemudian melepas begitu saja.

Khusus untuk konteks di Indonesia, studistudi good governance terkait dengan dimensi aktor lebih banyak mengeksplorasi keterlibatan negara sebagai aktor tunggal. Narasi yang dibangun hanya dari satu sudut pandang, yaitu titk berangkat yang sejak awal menyoroti negara. Akibatnya, kesimpulan penelitian sering berakhir pada penghakiman negara secara sepihak. Karena itu, posisi negara sebagai aktor tunggal dalam kecamata kajian good governance menjadi sangat terbatas. Kehadiran aktor negara secara tunggal justru berpotensi mengikis keterlibat aktor lain diluar negara. Yang dalam parkteknya, kelalaian pada praktek good governance tidak sepenuhnya hadir karena ketidakberdayaan negara. Atau jika memang pada tataran praktis, good governance menjelma menjadi sistem tata kelola yang mengakuisisi kepentingan aktor lain diluar negara, termasuk akuisis kepentingan pada dimensi publik yang lebih luas, peran ini tidak secara tunggal dimainkan oleh negara. Sangat penting untuk melihat relasi lain diluar dari negara yang secara politik membangun relasi dengan negara diatas konteks kebijakan baik di daerah maupun untuk skala nasional.

Terlepas debat diatas, apa yang disuguhkan oleh kedua kubu sangat penting untuk memahami perkembangan good governance baik untuk skala konsep maupun praktek. Kedua kubu telah berkontribusi besar khususnya untuk menunjukan sisi baik sekaligus sisi buruk praktek good governance yang selama ini berlangsung di Indonesia. Setidaknya studi sebelumnya telah memetakan praktek governance di dua dimensi, yaitu proses dan aktor yang terlibat. Meskipun dalam perjalanannya gagasan yang dibangun sangat kontradiktif.

Hanya saja, kedua kubu tidak menyelami lebih jauh tentang bagaimana aktor pada good governance saling terikat antara satu dengan yang lainnya. Penjelasan untuk keterlibatan aktor good governance masih menjadi dimensi yang sangat minim untuk di persoalkan oleh para sarjana. Kalaupun ada yang mengangkat keterlibatan aktor, jangkuannya terhenti hanya sebatas melihat bagaimana kedua aktor mampu terserap pada satu kesamaan yang menjadi nilai bersama. Tidak lebih jauh memotret sisi konflik yang terjadi pada aktor governance. Lebih spesifik pada aktor good financial governance. Dimensi konflik menjadi sangat penting dalam good financial governance, sebab kehadiran ketiga aktor dengan value yang berbeda sangat mungkin berdampak pada cara pandang hitunghitungan kebijakan yang juga sangat kontradiktif.

\section{TINJAUAN PUSTAKA}

\section{The Development of Good Financial Governance: From Good Governance to Good Financial Governance}

Di banyak tempat di dunia, good financial governance sebagai konsep yang diadopsi dari good governance menjadi semakin familiar. Popularitas good financial governance seiringan dengan perkembangan kepercayaan masyarakat luas kepada good governance yang tumbuh sebagai salah satu skema pemerintahan. Terbukti, dibanyak tempat good governance telah berkontibusi besar terhadap pembangunan dibanyak negara, termasuk di Indonesia (Eckardt, 2006:3). Oleh banyak aktor, good governance dianggap sangat tepat sebagai perpaduan banyak aktor dalam mengembangkan potensi suatus negara. Meski demikian, good governance dibanyak tempat juga selalu ditafsirkan secara beragam. Negara, lembaga donor, swasta serta civil society, masing-masing menafsirkan good governance dari titik berangkat politik yang berbeda. Perbedaan definisi ini yang kemudian menjadikan 
konsep good governance sumber konflik oleh aktor. Namun diatas perbedaan itu, ada satu konsensus yang diakui secara general di hampir seluruh negara yang menerapkan good governance, diantaranya tentang prinsip akuntabilitas, supremasi hukum dan legitimasi. Penerapan prinsip yang kemudian diterapkan kembali untuk good financial governance.

Di Jerman, good financial governance merupakan pengembangan dari good governance. Basis konsep good financial governance hampir serupa dengan good governance, yaitu sama-sama melihat proses yang berlangsung pada pemerintahan. Hanya saja, cakupan pada good financial governance lebih spesifik pada dimensi keuangan publik. Gagasan good financial governance adalah praktek tata kelola pemerintahan yang mendorong proses akuntabilitas, supremasi hukum dan legitimasi (Eckardt, 2006:4-5).

"For many years now Good Governance has been recognised as a central element of the promotion of development by partner countries and donors. This is not least emphasised in the millennium declaration. Perceptions and definitions of Good Governance differ internationally between institutions, albeit not significantly. There is a broad consensus concerning the general principles, i.e. legitimacy, accountability, the rule of law, performance and development-oriented national government, in particular in terms of social justice" (Eckardt, 2006: 4-5).

Lokus kajian dari good financial governance sepanjang proses kebijakan yang berlangsung pada sektor keuangan, mulai dari pengadiministrasian, perencanaan kebijakan, perumusan kebijakan, pengendalian serta kontrol dan evaluasi kebijakan keuangan. Dikatakan sebagai good financial governance ketika sepanjang proses perencanaan hingga kontrol untuk kebijakan keuangan mengadopsi prinsip-prinsip good financial governance yaitu prinsip akuntabilitas, supremasi hukum dan legitimasi.

Sementara bagi KFW Development Bank Competence Centre Development, Governance and Crisis, membangun definisi yang berbeda dengan good financial governance Eckardt (2006:4-5). Bagi Development Bank Comperence Development
(2016), good financial governance adalah tata kelola yang menekan pada dua aspek, yaitu aspek efisien dan bertanggung jawab. KFW Development membangun gagasan tentang efisien dan bertanggung, sebab proses pengamatan tentang good financial governance berlangsung pada penerimaan negara seperti pajak.

"Good financial governance is good governance in public finance. This includes that governments manage their expenditures in an efficient, transparent and accountable way whilst also collecting appropriate and fair taxes. Development cooperation contributes to good financial governance in partner countries by supporting ministries and other authorities responsible for public spending, tax administrations, audit institutions, parliaments and civil society" (Development Bank Comperence Development, 2016).

Sehingga, dalam Development Bank Comperence Development (2016) secara praksis, untuk menciptakan pembangunan dan pemerintahan yang baik, penekanan utama yang harus dilakukan adalah memberikan keterbukaan dan pertanggung jawaban pada publik, terhadap apa yang telah diterima dan akan dilakukan oleh negara dari uang hasil penerimaan seperti alokasi anggaran yang bersumber dari pajak.

Di Indonesia, konsep good financial governance belum terlalu familiar. Good financial governance secara gamblang disetarakan dengan good governance. Para sarjana menggunakan konsep good governance untuk menjelaskan tata kelola yang berlangsung di semua sektor seperti sektor lingkungan, pemerintahan dan keuangan (Hajar:2015, Hein: 2015: Sagales, dkk: 2015). Konsep ini digunakan secara bergantian, baik untuk tata kelola pada sektor lingkungan, tata kelola di ranah pemerintahan maupun untuk tata kelola untuk keuangan. Jangkuannya hanya sebatas mengetahui bagaimana tata kelola yang baik harus dilakukan.

Untuk tata kelola pada sektor lingkungan, konsep good governance lebih dimaknai dengan penguatan kontrol antara aktor pada good governace yang terlibat pada sektor lingkungan. Penguatan kontrol dilakukan dengan intensifikasi checks and balances (Hein, 2015:77-100). Dasar penerapan checks and balances sebagai upaya untuk 
meminimasir kerusakan lingkungan. Sebab, bagi pendekatan lingkungan, good governance akan menjadi petaka ketika konsep ini tidak diarahkan untuk segera mungkin mencegah deforestasi. Kekhawatiran ini muncul dengan melihat konsep good governance untuk sektor lingkungan telah meramba hingga ke pemerintah daerah, yang kemungkinan besarnya menjadikan daerah sebagai pelaku tunggal. Pembenaran deforestasi dengan berlindung pada good governance sangat mungkin dilakukan oleh pemerintah daerah. Sehingga, pencegahan atas deforestasi dilakukan dengan cara mendorong good governance. Akhirnya, konsep yang lazimnya digunakan untuk pemerintahan kini diduplikasi pada sektor lingkungan.

Tidak hanya itu, good governance juga digunakan untuk menjelaskan fenomena pemerintahan. Good governance menjadi konsep yang begitu diagungkan di tahun 1997/1998 yang bersamaan dengan proses transisi di Indonesia dari orde baru ke reformasi. Konteks ini yang kemudian menjadikan good governance tidak hanya sebatas konsep teoritis untuk menjelaskan tentang peristiwa yang berlangsung pada pemerintahan, tetapi pada saat itu good governance juga digunakan sebagai salah satu skema kerja yang harus diterapkan oleh pemerintahan di Indonesia pasca orde baru, apalagi saat itu good governance bergadengan dengan gelombang desentralisasi yang terus berlangsung di berbagai daerah Indonesia (Hajar: 2015, Voorst:2015, Fukuoka: 2014). Dengan situasi seperti ini, good governance mendapat ruang yang begitu besar di Indonesia. Situasi transisi politik salah satu sebab konsep ini begitu mudah diterima di hampir semua tingkatan pemerintahan di Indonesia.

Perkembangan selanjutnya good governance mulai lebih spesifik dengan melihat tata kelola yang berlangsung pada sektor keuangan. Pada dimensi ini, good governance menjadi lebih rinci. Konsentrasi lebih kecil, dan perhatian yang dibangun lebih besar. Pada dasarnya, good governance untuk sektor kelola keuangan lebih mengedepankan akuntabilitas. Good governance mengambil peran sebagai skema kerja yang harus memberikan penjelasan kepada publik terhadap lalu lintas keuangan pemerintah baik di skala daerah maupun untuk pemerintah pusat. Untuk sektor keuangan, sebagian sarjana sepakat menggunakan prinsip akuntabilitas sebagai penerapan good govenance (Nabiha: 2014, Mc Leond: 2014, and Kewo: 2017).
Secara konseptual, akuntabilitas pada pengelolaan keuangan yang sering dimanifestasikan sebagai penerapan good governance. Pada tataran praksis, good governance yang berlangsung di sektor keuangan hanya sebatas dorongan untuk segera mungkin mengimplementasikan prinsip-prinsip good governance. Jika pada good governance mengenal prinsip seperti akuntabilitas, transparansi dan partisipatif, maka prinsip ini yang juga digunakan dalam mengelola keuangan. Sehingga dari penjelasan singkat diatas tentang perkembangan good governance di berbagai sektor, para sarjana sering berakhir dengan sebuah kesimpulan yang berbeda dalam memahami good governance, namun sebagian besar para sarjana sampai pada kesapahaman yang sama tentang prinsip good governance (Akuntabilitas, transparansi dan partisipasi). Hal ini, menunjukan bahwa perbedan argumen yang dibangun sejak awal hanyalah untuk menunjukan perbedaan sudut pandang yang dipilih oleh para sarjana, namun ketika berbicara good goverance secara universisal hampir semua gagasan setuju bahwa good governace pada tata kelola keuangan sebenarnya berbicara tentang prinsip good governance.

Sehingga menjadi jelas, bahwa good financial governance mengambil jarak yang sangat jauh dengan good governance. Perbedaan itu muncul dari lokus kedua konsep tersebut. Good governance menaruh konsen sebatas pada pemerintahan sementara good financial governance lebih spesifik pada sektor keuangan. Namun, pada aspek yang lain, kedua konsep memiliki irisan persamaan yang saling berkaitan. Antara good financial governance dan good governance masing-masing mengedepankan prinsip-prisnip seperti akuntabilitas, transparansi, partisipasi sebagai prinsip dalam pengelolaan baik untuk pemerintahan maupun untuk keuangan.

\section{METODE PENELITIAN}

Penelitian berlangsung di Kota Makassar dan PT. Gowa Makassar Tourism Development (GMTD, Tbk.). GMTD, Tbk. adalah perusahaan yang bergerak di sektor pengembangan perumahan dan parawisata. Menggunakan metode analisis isi. Pengumpulan data dilakukan dengan merujuk pada sumber utama informasi pada laporan BPS kota Makassar serta dokumen laporan tahunan PT. GMTD. Tbk, lebih spesifik pada laporan kepemilikan saham dan divestasi saham sejak tahun 
2015 sampai tahun 2017. Fokus peneilitian dipusatkan pada hubungan aktor yang terbangun antara pemerintah kota Makassar dengan PT. GMTD, TBk.

Selanjutnya, analisis data dilakukan dengan membanding laporan tahunan PT. GMTD, Tbk dengan keadaan sosial ekonomi pemerintah kota Makassar yang rujukan datanya pada laporan rutin BPS kota Makassar. Kemudian untuk memberikan penjelasan hasil temuan dengan menyandingkan kedua sumber data, peneliti kemudian menggunakan pendekatan aktor good financial governance untuk menjelaskan lebih jauh tentang ketersediaan data yang ditemukan. Studi literatur sebagai tahap terakhir dilakukan pada penelitian ini untuk memperkuat hasil analisi yang telah dibangun. Studi literatur digunakan untuk mengkonfirmasi temuan berdasarkan data lapangan dengan penjelasan dari berbagai kasus yang perna terjadi di banyak tempat.

\section{HASIL DAN PEMBAHASAN}

\section{Exclusivity of Good Financial Governance}

Berbagai kasus distorsi yang lahir dari praktek good financial governance sebagai imbas dari adanya eksklufitas aktor. Konsep eksklusifitas aktor adalah sebuah fenomena governance yang muncul karena adanya hubungan aktor yang berlangsung pada relasi yang berbeda (Angelis:2015-26). Dengan eksklusifitas aktor, arena governance tidak lagi menjadi arena bersama, tetapi berubah menjadi arena eksklusif. Imbasnya, prinsipprisnip yang ditawarkan oleh good financial governance sebatas menjadi slogan, seperti akuntabilitas, partisipasi serta kepastian hukum. Kalaupun dalam prakteknya, prinsip good financial governance harus diterapkan, maka prinsip yang dipakai hanya bagi yang menguntungkan aktor yang kuat. Pada kasus hubungan kemitraan pemerintah kota Makassar dengan PT. GMTD, Tbk prinsip kepastian hukum menjadi prinsip yang harus ditampilkan dalam membangun relasi keimintraan. Bukan karena prinsip ini bagian dari apa yang dikehendaki oleh good financial governance, dibalik itu penerapan prinsip kepastian hukum lebih dekat pada kepentingan menjaga posisi aktor dalam relasi good financial governance.

Kepastian hukum sangat penting untuk menjaga eksistensi relasi yang berlangsung pada aktor good financial governance. Dimensi ini, memberikan kepastian secara normatif tentang siapa dan bagaimana relasi itu harus terbangun oleh sesama aktor. Kepastian hukum pada good financial governance yang berlangsung pada pemerintah kota Makassar dengan PT. GMTD, Tbk tercermin dari perda No. 6 Tahun 1992 tentang penyertaan modal Daerah. Secara normatife, perda inilah yang kemudian menjadi basis pijakan pada relasi aktor yang akan terbentuk.

Begitupun pada prinsip yang lain, seperti akuntabilitas dan partisipasi. Pada prakteknya prinsip akuntabilitas sebatas untuk memastikan relasi antara aktor terjaga. Memang benar, bahwa akuntabilitas dan partisipasi terus diagungkan sebagai pilar menuju tata kelola keuangan yang lebih baik, tetapi pada dimensi yang lain akuntabilitas dan partisipasi berlangsung dengan pincang. Akuntabilitas dan partisipasi terbatas untuk dimensi-dimensi yang menguntungkan satu pihak, sementara konsep yang sama tidak digunakan untuk aktor good financial governance secara umm, setidaknya untuk masingmasing aktor yang terlibat.

Pada kasus hubungan kemintraan yang berlangsung antara pemerintah kota Makassar dengan PT. GMTD, Tbk, prinsip akuntabilitas dan partisipasi yang diberikan cenderung tertutup dan sangat terbatas. Aktor pada good financial governance hanya mendapat porsi akuntabilitas dan partisipasi yang sangat berbeda-beda. Tidak semua aktor pada good financial governance punya porsi yang sama dalam hal akuntabilitas dan partisipasi. Salah satu bentuk konkret yang bisa dilihat adalah posisi aktor pada hubungan kemitraan PT. GMTD, Tbk berikut ini.

Aktor yang menduduki jabatan strategis adalah mereka yang memiliki relasi dan kedetakan baik secara ekonomi maupun secara politik. Sementara aktor lain, yang meskipun sama-sama aktor good financial governance sulit untuk mendapatkan ruang pada posisi yang lebih penting. Hal ini tentu sangat berdampak pada dimensi pengambilan kebijakan. Aktor yang punya relasi politik punya akses yang lebih besar, sebaliknya diluar dari aktor diatas akan sulit untuk punya ruang bahkan untuk mempengaruhi kebijakan. Sementara jika melihat peta aktor yang terbangun pada relasi good financial governance setidaknya ada enam aktor yang secara politik sudah tentu harus punya akses yang sama, sebab ini kaitannya dengan prinsip 
partisipasi sebagaimana yang ditawarkan oleh konsep good financial governance.

Tepat disnilah, apa yang disebut eksklusitas aktor pada good financial governance itu muncul. Secara normatif benar bahwa sesama aktor punya kesempatan yang sama pada tata kelola mulai dari perencanaan kebijakan hingga pada evaluasi kebijakan, tetapi dilapangan, muncul akuisi aktor terhadap aktor lain yang lebih lemah secara politik. Di saat yang sama, produk kebijakan apapun yang dihasilkan oleh aktor pada good financial governance juga harus di ikuti oleh aktor lain, termasuk aktor yang hanya mendapat ruang keterlibatan sangat kecil.

\section{Capital of Good Financial Governance}

Ekslusifitas aktor pada good financial governance sebagai fenomena yang muncul karena adanya penguasaan sumber daya yang tidak merata (Angelis, 2015-27). Pada kasus untuk hubungan kemitraan yang berlangasung antara pemerintah kota Makassar dengan PT. GMTD, Tbk penguasaan sumber daya yang dimaksud adalah perbedaan saham. Posisi aktor pada hubungan kemintraan sebagai konsekuensi dari good financial governance sangat di pengaruhi oleh seberapa besar saham yang dimiliki oleh masing-masing aktor. Semakin besar kepemilikan saham yang dimiliki oleh aktor, maka posisi yang terbangun pada relasi aktor pada good financial governance juga akan semakin besar, sebaliknya ketika saham yang dimiliki pada relasi kemintraan cenderung kecil, maka posisi aktor pada kecamata good financial governance juga akan semakin kecil.

Untuk hubungan kemintraan yang berlangsung pada pemerintah kota Makassar dengan PT. GMTD, Tbk. Dalam relasi aktor yang dibangun, pemerintah kota Makassar memiliki saham jauh lebih kecil dari kepemilikan saham secara keseluruhan pada PT. GMTD, Tbk .Sampai akhir tahun 2017, kepemilikan saham pemerintah kota Makassar yang tercata pada PT. GMTD, Tbk hanya sebesar 6, $50 \%$ atau setara dengan 3.300.000.000, Di banding dengan aktor yang lain, kepemilikan saham yang dimiliki oleh pemerintah kota Makassar berada pada posisi paling rendah. Sebagai konsekuensi timbal baliknya, posisi ini membuat posisi pemerintah kota Makassar dalam relasi aktor pada good financial governance sedikit mengalami kesulitan.
Tabel. 2. Kepemilikan Saham Gowa Makassar Tourism Development Coorporation (GMTD)

\begin{tabular}{|l|c|}
\hline \multicolumn{1}{|c|}{$\begin{array}{c}\text { Nama Pemilik } \\
\text { Saham }\end{array}$} & Total Modal Disetor \\
\hline $\begin{array}{l}\text { Public (each below } \\
5 \%)\end{array}$ & IDR 17.769.000.000 \\
\hline $\begin{array}{l}\text { PT. Makassar } \\
\text { Permata Sulawesi }\end{array}$ & IDR 16.500.000.000 \\
\hline $\begin{array}{l}\text { Pemerintah Daerah } \\
\text { Tingkat I Sulawesi } \\
\text { Selatan }\end{array}$ & IDR 6.600.000.000 \\
\hline $\begin{array}{l}\text { Pemerintah Daerah } \\
\text { Tingkat II } \\
\text { Kabupaten Gowa }\end{array}$ & IDR 3.300.000.000 \\
\hline $\begin{array}{l}\text { Pemerintah Daerah } \\
\text { Tingkat II } \\
\text { Kotamadya } \\
\text { Makassar }\end{array}$ & IDR 3.300.000.000 \\
\hline $\begin{array}{l}\text { Yayasan Partisipasi } \\
\text { Pembangunan } \\
\text { Sulawesi Selatan }\end{array}$ & IDR 3.300.000.000 \\
\hline
\end{tabular}

Sumber: Idnfinancial

Perbedaan saham tidak hanya berdampak pada perbedaan output berupa dividen yang diterima oleh masing-masing aktor. Lebih dari itu, perbedaan saham menjadi pemicu utama munculnya relasi politik yang berbeda oleh masing-masing aktor. Penguasaan saham inilah yang kemudian pada tulisan ini saya sebut sebagai "capital pada good financial governance”. Dengan capital good financial governance, aktor yang secara normatife punya kedudukan yang sama dalam kacamata good governance ataupun good financial governance, tetapi dengan capital yang berbeda, persamaan prinsip pada terminologi "good" tidak berlangsung pada arena praktis. Capital good financial governance menjadi pendorong relasi aktor yang dampaknya pada ruang dan akses pengambilan kebijakan yang juga sangat timpang oleh masingmasing aktor.

\section{KESIMPULAN}

Good financial governance adalah sebuah gagasan yang didorong untuk menerapkan prisnipprinsip good governance bekerja di ranah publik yang lebih spesifik. Adalah sektor keuangan khususnya penerimaan dan belanja pemerintah daerah yang menjadi perhatian utama pada good 
financial governance. Gagasan ini sejatinya menginginkan pengelolaan keuangan dengan prinsip-prinsip partisipasi, transparansi, kepastian hukum sebagaimana prinsip-prinsi ini lebih dahulu diterapkan pada good governance. Tujuannya, good financial governance menghendaki sebuah wajah baru untuk pengelolaan keuangan sektor publik. Sistem pengelolaan yang tidak lagi bertumpu pada persoalan administrasi semata yang hanya berfokus pada internal pemerintah, good financial governance ingin melampui keterlibatan pemerintah dengan membangun jejaring kemitraan pada aktor diluar pemerintahan.

Namun, seiringan dengan itu good financial governance yang membangun jejaring kemitraan dengan aktor diluar pemerintah menimbulkan perkara baru. Ekslusifitas aktor salah satunya. Terminilogi "good" melahirkan "ekslusifitas" khususnya pada aktor good financial governance. Jejaring aktor melalui hubungan kemitraan berubah menjadi hubungan yang saling mengontrol antara satu dengan yang lainnya. Aktor yang memiliki sumber daya pada relasi aktor good financial governance punya ruang lebih leluasa untuk mengendalikan arah dan produk kebijakan, sementara aktor yang hanya mempunyai sumber daya kecil dibanding dengan yang lainnya juga memiliki akses pada pengambilan kebijakan yang sangat terbatas. Perbedaan sumber daya yang sekaligus mencipatkan relasi saling mengontrol antara aktor pada good financial governance mengeliminasi sebagian dari aktor yang terlibat. Proses eliminasi berlangasung dengan "mengeksklusifkan" beberapa aktor yang dianggap berbeda garis politik dengan aktor yang lain, sementara aktor yang cenderung berdiri pada kepentingan politik yang sama akan mendapat ruang lebih besar. Proses ekslusif yang berlangsung dilakukan oleh aktor yang memiliki akses dan sumber daya yang lebih besar, yang sebelumnya kita sebut sebagai aktor yang mengontrol aktor lain yang lebih lemah, baik dalam hal politik maupun secara ekonomi.

Proses "eksklusifitas aktor" berlangsung di sepanjang arena pengambilan keputusan, mulai dari perencanaan hingga evaluasi kebijakan. Benar bahwa sepanjang proses itu, prinsip-prisnip good financial governance seperti akuntabilitas, partisipasi dan kepastian hukum digunakan untuk meghasilkan produk kebijakan yang lebih baik.
Tetapi, pada konteks kasus yang menjadi pengamatan pada penelitian ini, sepanjang proses tersebut yang hadir justru eksklusifitas aktor. Proses eksklusifitas aktor khususnya berlangasung di tataran internal. Ekslusifitas aktor dilakukan dengan memberikan jabatan strategis kepada aktor yang punya garis politik yang searah, sementara aktor yang cenderung berbeda kepentingan baik secara ekonomi dan politik tidak berada pada jabatan yang penting. Hal ini sangat berdampak besar, pasalnya keberadaan aktor pada posisi strategis akan sangat menentukan arah dan masa depan kebijakan pada konteks organisasi tersebut, seperti pada hubungan kemitraan yang berlangsung.

\section{REFERENSI}

Angelis, Massimo De. 2015. Economi Politic of Governance Neoliberalisme Global. In Membongkar Proyek Pembangunan Neoliberal. Suluh Pergerakan. Vol. 1 Desember 2015.

Eckardt, Ute. 2008. Good financial GovernanceGood Governance in Public Finance. Deutsche Gesellschaft für Technische Zusammenarbeit (GTZ) gmbh DagHammarskjöld-Weg 1-5.

Fernandes, Adji Achmad Rinaldo. Raffles Brotestes Panjaitan. 2016. The effect of community and company participation and implementation of good forest fire governance on the forest fire policy in Indonesia. Journal of Management Development, Vol. 37 Iss 1 pp. 76-87

Fossati, Diego. 2017. A Tale of Three Cities: Electoral Accountability in Indonesian Local Politics. Journal of Contemporary Asia. 10.1080/00472336.2017.1376345

Fukuoka, Yuki \& Ina Choi. 2014. Co-opting Good Governance Reform: The Rise of a Not-soReformist Leader in Kebumen, Central Java. Asian Journal of Political Science, 2015 Vol. 23, No. 1, 83-101.

Hajar, Bakhttiar. 2015. Bureaucracy and Governance in Indonesia: Study on West Sulawesi Province. Procedia Economics and Finance 23 ( 2015 ) $223-227$ 
Hein, Lars \& Aritta Suwarno. 2015. Governance, Decentralisation and Deforestation: The Case of Central Kalimantan Province, Indonesia. Quarterly Journal of International Agriculture 54 (2015), No. 1. 77-100.

Husen, La Ode. Dkk. 2017. Independence And Accountability, Supreme Court In The Implementation: The Power Of Judgment In Indonesia. Journal of Interdisciplinary Research (IJIR) Vol-3, Issue-5, 2017

Kewo, Cecelia Lelly. 2017. The Influence of Internal Control Implementation and Managerial Performance on Financial Accountability Local Government in Indonesia. International Journal of Economics and Financial Issues, 2017, 7(1), 293-297.

KFW Development Bank Competence Centre Development, Governance and Crisis. Good Financial Governance. Palmengarten strasse 5-9 60325 Frankfurt Germany.

Kittie Uda, Saritha, Schouten. Greetje, Hein, 2018. The institutional fit of peatland governance in Indonesia. Land Use Policy. 03.031

Mc Leod, Ross \& Harun Harun. 2014. Public Sector Accounting Reform at Local Government Level in Indonesia. Financial Accountability \& Management, 30(2), May 2014, 0267-4424.

Nabiha, Siti \& Hasan Basri. 2014. Accountability Of Local Government: The Case Of Aceh Province, Indonesia. Asia Pacific Journal of Accounting and Finance, Volume 3 (1), December 2014.

Pal, Sarmistha. Zaki Wahhaj. 2016. Fiscal Decentralisation, Local Institutions and Public Goods Provision: Evidence from Indonesia. Journal of Comparative Economics. 10.1016/j.jce.2016.07.004

Pierskalla and Audrey Sacks. 2016 Unpacking the Effect of Decentralized Governance on Routine Violence : Lessons from Indonesia. World Development. Vo. XX, PP. xxx-xxx. 2016.
Riyadi, Slamet. Santoso, Alim. 2018. Critical Perspective and Reconstruction Governance: Organization Management Zakat In Indonesia. Archives of Business Research - Vol.6, No.5

Sagales, dkk. 2015. Fiscal decentralization and regional disparities: The importance of good governance. Papers in Regional Science, Volume 94 Number 1 March 2015.

Ukhriyawati1. Catur F, Tri Ratnawati \& Slamet Riyadi. 2017. The Influence of Asset Structure, Capital Structure, Risk Management and Good Corporate Governance on Financial Performance and Value of The Firm through Earnings and Free Cash Flow As An Intervening Variable in Banking Companies Listed in Indonesia Stock Exchange. International Journal of Business and Management; Vol. 12, No. 8; 2017

Voorst, Roanne Van. 2015. Formal and informal flood governance in Jakarta, Indonesia Habitat International. Vol. Xxx. 1-6. https://www.idnfinancials.com/id/GMTD/PTGowa-Makassar-Tourism-Development-Tbk, Diakses Pada, 25 Mei 2018. 